\title{
IMPACT OF SUBCLINICAL ACUTE REJECTION ON RENAL GRAFT FUNCTION: RESULTS OF THREE-YEAR FOLLOW-UP
}

\author{
Vadims Suhorukovs ${ }^{\star, \star *}$ and Tatjana Tihomirova ${ }^{\star \star \star}$ \\ * Pauls Stradiṇš University Hospital, Latvian Transplantation Centre, Pilsoṇu iela 13, Rīga, LV-1002, LATVIA; \\ vadim.suhorukov@inbox.Iv \\ ** Rīga Stradiṇš University, Transplant Laboratory, Dzirciema iela 16, Rīga, LV-1007, LATVIA \\ ${ }^{* * *}$ Rīga $1^{\text {st }}$ Hospital, Bruṇinieku iela 5, Rīga, LV-1001, LATVIA
}

Communicated by Rafails Rozentāls

\begin{abstract}
Notwithstanding that in the last years the immediate results of kidney transplantation have been improved, there has been no adequate improvement of long-term results. Therefore, more attention is being paid to the so-called subclinical rejections of renal grafts, detected by protocol biopsies, as a possible factor affecting renal function in late period. The aim of this study was to determine the frequency of subclinical rejections and their impact on further renal graft function. Within the frame of the study 40 protocol biopsies were performed in 26 patients with immediate and stable renal graft function. In $17(65.4 \%)$ of them a subclinical rejection of IA-IIA degree was detected. In nine patients with subclinical rejection, treatment with steroids was applied, while eight recipients did not receive any additional therapy. In follow-up, in a period of three years there was no statistically significant difference in blood creatinine level, glomerular filtration rate, number of clinical rejections during the monitoring period, and three-year survival of the transplanted kidney in patients, regardless of where the treatment of subclinical rejection was applied. The results of our study did not indicate any impact of subclinical rejection on renal graft function in the late post-operation period.
\end{abstract}

Key words: subclinical rejection, renal transplant protocol biopsy, renal graft function.

\section{INTRODUCTION}

During the last ten-year period, when implementation of new immunosupressors has been applied, the immediate results of renal transplantation have improved significantly, reducing the number of clinical acute rejections and early graft losses. However, no success has been reached in similar progress also in the late post-transplantation period and to increase significantly the functioning period of transplanted kidneys (Meier-Kriesche et al., 2004). Prevention of the development of glomerular sclerosis, interstitial fibrosis and tubular atrophy, which is one of main causes of chronic renal graft dysfunction, is still important.

In the 1990s, some transplantation centres implemented the protocol of puncture biopsies of renal transplants - scheduled biopsies irrespective of graft function. The histological examination of received tissues samples in some patients without any clinical manifestation of renal dysfunction showed changes typical for the acute rejection reactions (Rush et al., 1994; 1995). This phenomenon was called subclinical rejection. Further studies led to conclusion made by some authors of a relation between the subclinical rejection and the development of chronic nephropathy in the renal transplants and the reduction of their functioning period
(Miyagi et al., 2005; Thierry et al., 2011). In consequence, there arose a need for treatment of the subclinical rejections. It was observed that treatment of subclinical rejections with corticosteroids in the early post-operation period improves the remote results (Rush et al., 1998). Other authors also detected a positive effect of treatment of subclinical rejections (Mengel et al., 2007).

However, there still is no united opinion concerning the prognostic significance of subclinical rejections and the positive effect of their treatment on outcome of kidney transplantation (Roberts et al., 2004; Kuypers, 2008).

The aim of the study was to investigate the frequency of subclinical rejections in patients with stable renal graft function during the first month after the operation and during three-year follow up, and their impact on further function of renal transplants.

\section{MATERIALS AND METHODS}

From 1 January 2007 to 28 February 2009, 40 protocol biopsies in 26 patients with immediate and stable renal graft function were carried out in the early post-operation period 
NUMBER OF PROTOCOL BIOPSIES IN PATIENTS WITH IMMEDIATE AND STABLE GRAFT FUNCTION

\begin{tabular}{cc}
\hline Number of biopsies & Number of patients \\
\hline 1 biopsy & 16 patients \\
2 biopsies & 6 patients \\
3 biopsies & 4 patients
\end{tabular}

in the Latvian Renal Transplantation Centre (Table 1). As induction immunosupression monoclonal antibodies against interleukin-2 receptors were used: $20 \mathrm{mg}$ i/v Basiliximab on the operation day and on the fourth post-operation day, $1 \mathrm{mg} / \mathrm{kg} \mathrm{i} / \mathrm{v}$ Daclizumab on the operation day and on the 15 th post-operation day or polyclonal antibodies - 1.5-3 $\mathrm{mg} / \mathrm{kg} \mathrm{i} / \mathrm{v}$ anti-T lymphocyte globulin $(A T G)$ during the first 3-5 days after the transplantation. As supporting immunosupressive therapy, the patients received $500 \mathrm{mg}$ methylprednisolone intravenously on the operation day with further dose reduction during the first five post-operation days; $0.5 \mathrm{mg} / \mathrm{kg} /$ day $\mathrm{p} / \mathrm{o}$ prednisolone with continuous dose reduction on average up to $20 \mathrm{mg} /$ day after a month and up to 5-10 mg/day after six months after the operation; inhibitors of calcineurin - Ciklosporine A initially at $3 \mathrm{mg} / \mathrm{kg} /$ day with further dose correction in accordance with the level in blood $(\sim 150 \mathrm{ng} / \mathrm{ml}$ during the first three months after the transplantation and $\sim 100-150 \mathrm{ng} / \mathrm{ml}$ thereafter); mycophenolate mofetil - Cell-Cept, $2 \mathrm{~g}$ per day.

For treatment of acute rejection, steroid pulse therapy was applied (500 mg methylprednisolone i/v for 3 days).

As immediate graft function was considered the condition where the serum creatinine level with adequate diuresis and without any substituting renal therapy during first 3-5 postoperation days decreased to $0.3 \mathrm{mmol} / \mathrm{l}$ or less. Usually, protocol biopsies were performed on the 3rd-4th post-operation week in patients with a serum creatinine level 0.2 $\mathrm{mmol} / \mathrm{l}$ or less, with normal body temperature, adequate diuresis and stable function of renal transplant, as these observations implied that the creatinine level fluctuation in the last seven days did not exceed 20\%. By necessity biopsy was repeated. As the participating patients had good and stable renal graft function, all biopsies were performed with the patient's consent after explanation of the aim and purpose of the procedure.
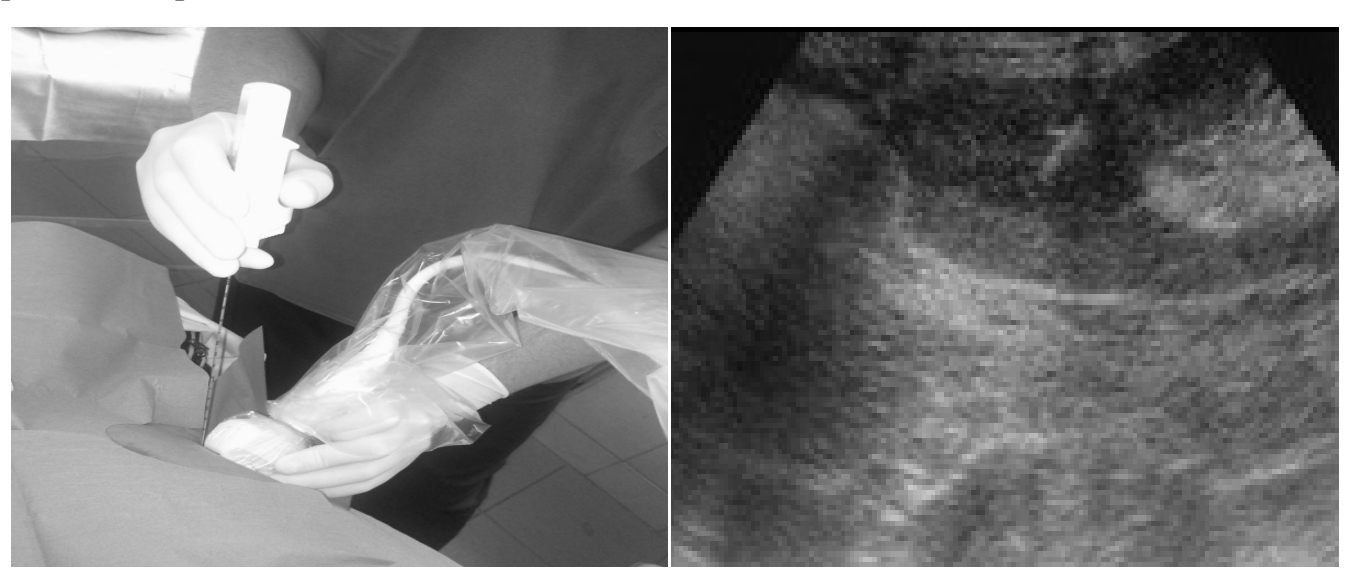

Fig. 1. Puncture biopsy of renal graft under ultrasonoscopy control.
The puncture biopsies were performed using an automatic biopsy device and a single-use puncture needle (18G) Vitesse or a single-use automatic biopsy needle Angiotech under ultrasonoscopic control in order to avoid any possible injury to adjacent structures - ureter, blood vessels, and intestines (Fig. 1). In order to increase the informational content received, usually two specimens of renal tissues from various sites were take. The samples were stained with hematoxylin-eosin, PAS-reaction and Masson method. Light microscopy was used for examination of preparations. Histological changes were evaluated in accordance with the Banff classification (Solez et al., 1993; 2007; Racusen et al., 1999). Acute rejections were considered as histological changes starting from IA and higher.

In the order to investigate the impact of subclinical rejections on further renal graft function, four recipient groups were selected:

group 1 - patients with immediate and stable renal graft function without any histological signs of acute rejection in the biopsy material $(\mathrm{n}=9)$;

group 2 - patients with immediate and stable renal graft function and with histological signs of acute rejection in the biopsy material, in whom treatment of subclinical rejection was applied $(n=9)$;

group 3 - patients with immediate and stable renal graft function and with histological signs of acute rejection, in whom treatment of subclinical rejection was not applied $(\mathrm{n}=8)$;

group 4 (control) - patients with immediate and stable renal graft function without any clinical signs of acute rejection, in whom the protocol biopsy was not performed $(n=54)$.

The study design was approved by the Ethics Committee of Rīga Stradinšs University. The follow-up period was three years.

The patient groups were compared using the following parameters:

- renal graft function one month after the operation and after three years (function was evaluated on the basis of serum creatinine level and glomerular filtration rate calculated by the Cockcroft-Gault formula); 
- number of acute clinical rejections during the follow-up period, approved by puncture biopsy;

- three-year survival of renal grafts.

For the analysis of parametric data we used the test one-way ANOVA (General Linear Model, Univariate). The results were considered as statistically reliable at $P \leq 0.05$.

For the analysis of non-parametric data we used the Chisquare and the Fisher's exact tests. The results were considered as statistically significant at $P \leq 0,05$.

The functioning period of the renal transplants was analysed using the Kaplan-Meier surveillance test.

\section{RESULTS}

Within the frame of the study, 40 protocol biopsies in 26 patients with immediate and stable renal graft function were performed. After the performed manipulation, no complications were observed that would require additional treatment. One patient developed a macrohematuria after the biopsy, which passed within three days without any additional intervention. Histological examination of the biopsy material in three patients did not detect any pathologic changes in the transplanted kidney, in two patients morphologic changes typical for BK viral infection were observed, and in four patients in the examined material was diagnosed as showing marginal changes. In 17 recipients with immediate and stable renal graft function without any clinical manifestations of dysfunction, morphological signs of acute rejection were detected: IA degree in 12 patients, IB degree in four patients and IIA degree in one patient (Table 2).

Nine patients with histological signs of acute rejection received steroid treatment. The subclinical rejection was not treated in the remaining eight recipients. Comparative analysis (Table 3) indicated that donor and recipient age, as well as the cold ischemia time were comparable among groups. Blood creatinine level and glomerular filtration rate did not significantly differ between groups one month after surgical manipulation and after three years, including the group of patients that did not receive treatment for subclinical rejec-
Table 2

RESULTS OF PROTOCOL BIOPSY IN PATIENTS WITH IMMEDIATE AND STABLE RENAL GRAFT FUNCTION

\begin{tabular}{l|c}
\hline \multicolumn{1}{c}{ Finding } & Number of patients \\
\hline Without pathologic changes & 3 \\
Signs of BK viral infection & 2 \\
Marginal changes & 4 \\
Signs of acute rejection & 17 \\
& IA degree -12 \\
& IB degree -4 \\
& IIA degree -1
\end{tabular}

tion of renal graft (Figs. 2, 3). The number of clinical acute rejections during the follow-up period also was similar among groups (Fig. 4). The three-year survival of a renal
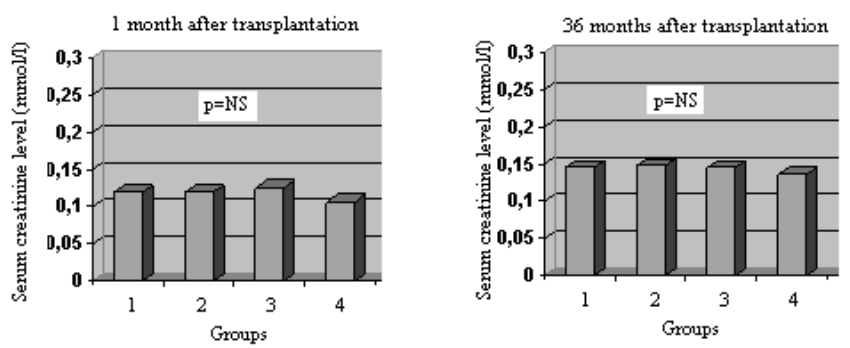

Fig. 2. Serum creatinine level after 1 month and after 36 months in patients without signs of subclinical rejection (SR) in biopsy material (group 1), with treated SR (group 2), with untreated SR (group 3) and control group patients (group 4). NS, differences among groups are not statistically significant.
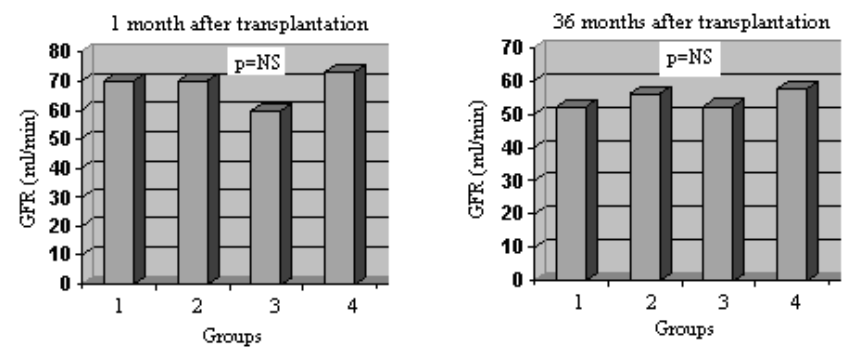

Fig. 3. GFR after 1 and after 36 months in patients without signs of subclinical rejection (SR) in biopsy material (group 1), with treated SR (group 2), with untreated SR (group 3) and control group patients (group 4). NS, differences among groups are not statistically significant.

Table 3

COMPARISON OF CLINICAL DATA AND GRAFT FUNCTION IN PATIENTS WITHOUT SIGNS OF SUBCLINICAL REJECTION (SR) IN THE BIOPSY MATERIAL (group 1), WITH TREATED SR (group 2), WITH UNTREATED SR (group 3) AND CONTROL GROUP PATIENTS (group 4)

\begin{tabular}{|c|c|c|c|c|}
\hline Index & $\begin{array}{c}\text { Group } \\
n=9\end{array}$ & $\begin{array}{c}\text { Group } 2 \\
n=9\end{array}$ & $\begin{array}{c}\text { Group } 3 \\
\mathrm{n}=8\end{array}$ & $\begin{array}{c}\text { Group } 4 \\
\mathrm{n}=54\end{array}$ \\
\hline Recipient's age (years) & $52.0 \pm 11,5$ & $46.0 \pm 15.1$ & $49.0 \pm 7.5$ & $46.1 \pm 16.0$ \\
\hline Cold ischemia time (hours) & $17.9 \pm 1.7$ & $16.7 \pm 2.1$ & $16.3 \pm 2.8$ & $16.7 \pm 5.0$ \\
\hline Donor's age (years) & $42.1 \pm 12.9$ & $51.1 \pm 13.5$ & $48.6 \pm 8.4$ & $44.9 \pm 16.2$ \\
\hline Serum creatinine after 1 month $(\mathrm{mmol} / \mathrm{l})$ & $0.119 \pm 0.022$ & $0.118 \pm 0.027$ & $0.125 \pm 0.035$ & $0.106 \pm 0.021$ \\
\hline Serum creatinine after 36 months $(\mathrm{mmol} / \mathrm{l})$ & $0.146 \pm 0.328$ & $0.147 \pm 0.330$ & $0.146 \pm 0.070$ & $0.136 \pm 0.037$ \\
\hline GFR after 1 month (ml/min) & $69.8 \pm 17.5$ & $70.1 \pm 22.5$ & $59.8 \pm 11.6$ & $73.1 \pm 15.2$ \\
\hline GFR after 36 months (ml/min) & $52.22 \pm 14.76$ & $56.14 \pm 20.03$ & $52.50 \pm 13.37$ & $57.70 \pm 16.31$ \\
\hline Clinical acute rejection during the follow up & $33.3 \%(3)$ & $33.3 \%(3)$ & $25 \%(2)$ & $16.7 \%(9)$ \\
\hline
\end{tabular}

period $(\%)$ 


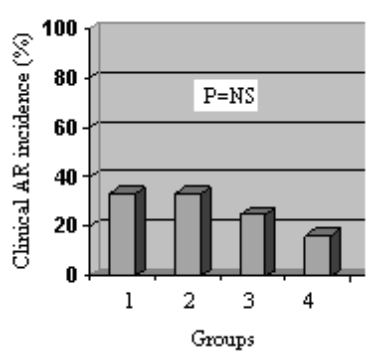

Fig. 4. Number of clinical acute rejection (AR) cases during the follow-up period in patients without signs of subclinical rejection (SR) in biopsy material (group 1), with treated SR (group 2), with untreated SR (group 3) and control group patients (group 4). NS, differences among groups are not statistically significant.

graft did not significantly differ between groups (Fig. 5). Two patients for whom biopsy material indicated signs of acute rejection, and who therefore received steroid treatment (group 2), lost their grafts during the follow-up period. One of these patients did not adhere to the immunosupressor administration regime, which resulted in development of steroid resistant rejection that was managed successfully. The other patient who developed acute clinical rejection of renal graft had a background of heavy acute pneumonia. Taking into account the heavy course of pneumonia and possible worsening of general condition in the event of rejection treatment with polyclonal antibodies, this was not applied. Within a month the patient restarted hemodialysis due to graft dysfunction.

In the control group, during the follow-up period three patients restarted hemodialysis due to graft nephropathy, and five patients died due to various causes with functioned renal graft.

\section{DISCUSSION}

Puncture biopsy is one of main and most frequently used method of diagnostics and differential diagnostics for pathologic conditions of renal graft. Taking in account that the procedure in most events is performed under ultrasonoscopic control, safety is sufficiently high, but as for any invasive manipulation, complications are still possible. According to published literature, the complication frequency

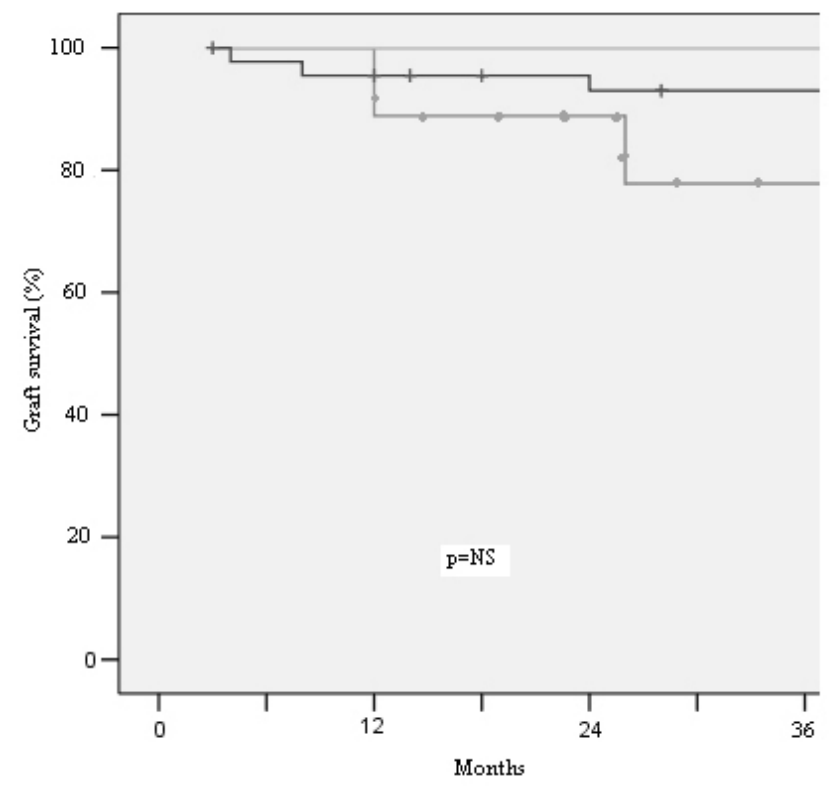

of puncture biopsies in transplanted kidneys is about $1 \%$ (Furness et al., 2003; Schwarz et al., 2005). Among possible complications are serious cases such as peritonitis and even irreversible damage of the renal graft. In our study we did not encounter heavy complications that arose from puncture biopsies.

Histological changes typical for acute rejection in the routine biopsy material in patients with stable renal graft functions were first decribed in the 1990s (Rush et al., 1994: 1995) and subsequently the number of studies of sibclinical rejections as a possible factor affecting further function of transplanted kidneys has increased. Some authors consider that subclinical rejections are subject to the treatment, as these rejections can cause further worsening of renal function (Kee et al., 2006; Moreso et al., 2006).

We did not find any negative impact of subclinical rejection on renal graft function during the three-year follow-up. The serum creatinine level and glomerular filtration rate did no significantly differ between patient groups one month after operation nor after three years. In the control patient group, protocol biopsies were not performed, but, taking in account the high percentage of subclinical rejections in our patient population $(60 \%)$, we can assume that also in this group more than $60 \%$ patients had subclinical rejections, which remained untreated. However, the blood creatinine level and the glomerular filtration rate in this group patients did not significantly different from those in patients without any signs of clinical rejection and with detected and treated subclinical rejections.

The number of acute clinical rejections and the three-year renal graft survival also did not significantly differ between groups, although in the patients group having received treatment for their subclinical rejection, the 3-year renal graft survival was lower in comparison with other groups. The two cases of graft loss of this group were not related with the factor being studied.

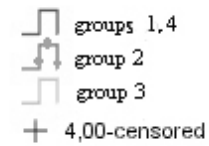

Fig. 5. 3-year graft survival in patients without signs of subclinical rejection (SR) in biopsy material (group 1), with treated SR (group 2), with untreated SR (group 3) and control group patients (group 4). 
Our study involved a relatively limited number of patients, as we only performed the protocol biopsies on informed consent of recipients. Therefore, some part of the control group patients are those having declined the protocol biopsy.

Although protocol biopsies have been recognized as a sufficiently safe method with insignificant number of complications, a possibility still exists. In the event of renal graft dysfunction the application of puncture biopsies is fully justified, but taking into account the obtained results, the application of puncture biopsies in patients with good and stable renal graft function is disputable.

In conclusion, although the percentage of subclinical rejections detected using protocol biopsies was rather high in our study, the three-years follow-up did not detected any negative impact of these rejections on renal graft function, even when they were not treated.

\section{REFERENCES}

Furness, P. N., Philpott, C. M., Chorbadjian, M. T., Nicholson, M. L., Bosmans, J. L., Corthouts, B. L. (2003). Protocol biopsy of the stable renal transplant: A multicenter study of methods and complication rates. Transplantation, 76, 969-973.

Kee, T., Chapman, J., O’Connel, P., Fung, C. L., Allen, R. D., Kable, K., Vitalone, M. J., Nankivell, B. J. (2006). Treatment of subclinical rejection diagnosed by protocol biopsy of kidney transplants. Transplantation, 82, 36-42.

Kuypers, D. R. (2008). Immunosuppressive drug therapy and subclinical acute renal allograft rejection: Impact and effect. Transplantation, 85, S25.

Meier-Kriesche, H. U., Schold, J. D., Srinivas, T. R., Kaplan, B. (2004). Lack of improvement in renal allograft survival despite a marked decrease in acute rejections rates over the most recent era. Amer. J. Transplant., 4, $378-383$.

Mengel, M., Gwinner, W., Schwarz, A., Bajeski, I., Franz, V., Broker, T., Becker, M., Neipp, M., Klempnauer, J., Haller, H., Kreipe, H. (2007). Infiltrates in protocol biopsies from renal allograft. Amer. J. Transplant., 7, $356-365$.
Miyagi, M., Ishikswa, Y., Mizuiri, S., Aikawa, A., Ohara, T., Hasegawa, A. (2005). Significance of subclinical rejection in early renal allograft biopsies for chronic allograft dysfunction. Clin. Transplant., 19, 456-465.

Moreso, F., Ibernon, M., Goma, M., Fulladosa, X., Hueso, M., Gil-Vernet, S., Cruzado, J. M., Torras, J., Grinvo, J. M., Seron, D. (2006). Subclinical rejection associated with chronic allograft nephropathy in protocol biopsies as a risk factor for late graft loss. Amer. J. Transplant., 6, 747-752.

Racusen, L. C., Solez, K., Colvin, R. B., et al. (1999). The Banff 97 working classification of renal allograft pathology. Kidney Int., 55 (2), 713-723.

Roberts, I., Reddy, S., Russel, C., Davies, D. R., Friend, P. J., Handa, A. J., Morris, P. J. (2004). Subclinical rejection and borderline changes in early protocol biopsy specimens after renal transplantation. Transplantation, 27, 1194-1198.

Rush, D. N., Henry, S. F., Jeffery, J. R., Schroeder, T. J., Gough, J. (1994). Histological findings in early routine biopsies of stable renal allograft recipients. Transplantation, 57 (2), 208-211.

Rush, D. N., Jeffery, J. R., Gough, J. (1995). Sequential protocol biopsies in renal transplant patients. Clinico-pathological correlations using the Banff schema. Transplantation, 59, 511-514

Rush, D., Nickerson, P., Gough, J., McKenna, R., Grimm, P., Cheang, M., Trpkov, K., Solez, K., Jeffry, J. (1998). Beneficial effects of treatment of early subclinical rejection: A randomized study. J. Amer. Soc. Nephrol., 9, 2129-2134.

Schwarz, A., Gwinner, W., Hiss, M., Radermacher, J., Mengel, M., Haller, H. (2005). Safety and adequacy of renal transplant protocol biopsies. Amer. J. Transplant., 5, 1992-1996.

Solez, K., Axelsen, R. A., Benediktsson, H., Burdick, J. f., Cohen, A. H., Colvin, R. B., Croker, B. P., Droz, D., Dunnil, M. S., Halloran, P. F. (1993). International standartization of criteria for the histologic diagnosis of renal allograft rejection: The Banff working classification of kidney transplant pathology. Kidney Int., 44, 411-422.

Solez, K., Colvin, R. B., Racusen, L. C., Sis, B., Halloran, P. F., Birk, P. E., Campbell, P. M., Cascalho, M., Collins, A. B., Demetris, A. J., Drachenberg, C. B., Gibson, I. W., Grimm, P. C., Haas, M., Lerut, E., Liapis, H., Mannon, R. B., Marcus, P. B., Mengel, M, Mihatsch, M. J., Nankivell, B. J., Nickeleit, V., Papadimitriou, J. C., Platt, J. L., Randhawa, P., Roberts, I., Salinas-Madriga, L., Salomon, D. R., Seron, D., Sheaff, M., Weening, J. J. (2007). Banff'05 Meeting Report: Differential Diagnosis of Chronic Allograft Injury and Elimination of Chronic Allograft Nephropathy (CAN). Amer. J. Transplant., 7, 518-526.

Thierry, A., Thervet, E., Vuiblet, V., Goujon, J. M., Machet, M. C., Noel, L. H., Rioux-Leclercq, N., Comoz, F., Cordonnier, C., Franēois, A., Marcellin, L., Girardot-Seguin, S., Touchard, G. (2011). Long-term impact of subclinical inflammation diagnosed by protocol biopsy one year after renal transplantation. Amer. J. Transplant., 11, 2153-2161.

Received 16 November 2012

\section{SUBKLĪNISKAS AKŪTAS ATGRŪŠANAS REAKCIJAS IETEKME UZ NIERES TRANSPLANTĀTA FUNKCIJU: TRĪS GADU NOVĒROŠANAS REZULTĀTI}

Neraugoties uz to, ka pēdējā laikā nieres transplantācijas rezultāti agrīnajā pēcoperācijas periodā uzlabojas, līdzīgi panākumi vēlīnajā periodā nav sasniegti. Līdz ar to arvien vairāk uzmanības tiek pievērsts ar protokola biopsijām atklātām subklīniskajām atgrūšanas reakcijām kā iespējamam faktoram, kas ietekmē nieres funkciju vēlīnajā periodā. Darba mērkị bija noteikt subklīniskas atgrūšanas reakcijas sastopamību un ietekmi uz nieres transplantāta funkciju. Pētījuma ietvaros tika veiktas 40 protokola biopsijas 26 pacientiem ar primāru un stabilu nieres transplantāta funkciju. No tiem 17 pacientiem tika konstatēta subklīniskas atgrūšanas reakcijas IA-IIA pakāpe. Deviniem pacientiem subklīniska atgrūšanas reakcija tika ārstēta ar steroīdiem, bet astoṇiem pacientiem papildus ārstēšana netika pielietota. Novērojot pacientus trīs gadus, seruma kreatinīna līmenis, glomerulāras filtrācijas ātrums, klīniskas atgrūšanas reakciju skaits un trīs gadu transplantātu dzīvildze statistiski neatškīrās pacientiem ar ārstētām un neārstētām subklīniskām atgrūšanas reakcijām. Veiktajā pētījumā subklīnisko atgrūšanas reakciju ietekme uz nieres transplantāta funkciju vēlīnā pēcoperācijas periodā netika konstatēta. 